\title{
Do television food commercials target children in Germany?
}

\author{
Tobias Effertz* and Ann-Christin Wilcke \\ Institute for Commercial Law, University of Hamburg, Max Brauer Allee 60, D-22765 Hamburg, Germany
}

Submitted 8 February 2011: Accepted 9 November 2011: First published online 14 December 2011

\begin{abstract}
Objective: To examine whether the German food industry directs commercials for unhealthy products to children and whether self-administered voluntary restrictions on the promotion of less healthy foods (the EU Pledge) are effective to mitigate this exposure.

Design: By analysing German data from television (TV) channels, advertised products were categorized and food products classified as core foods (healthy) and non-core foods (less healthy). Marketing techniques were documented. Food commercials were furthermore compared with commercials for toy products, and comparisons were made between advertising patterns before and after the EU Pledge. Setting: Data for ten German TV channels were recorded for two weekdays and two weekend days from 06.00 to 22.00 hours in 2007 and 2008. A second sample containing one weekday and one weekend day of three German TV channels was recorded again in 2010 for comparison in the same time period.

Subjects: In total 16062 advertisements from 2007-2008 and 2657 from 2010 were analysed.

Results: In 2007-2008 19.9\% of TV commercials were for food products, of which $73 \%$ were for non-core foods, $21 \%$ for core foods and $6 \%$ not classified. In three specified channels widely viewed by children and youth, $14.5 \%$ of commercials were for food products, of which $88.2 \%$ were for non-core foods. Commercials for unhealthy foods were broadcast significantly more often during children's peak viewing and in children's programmes, with a higher use of promotional characters and premiums than found in commercials for non-food products. In 2010 , analysis of the three specified channels found that $18.5 \%$ of commercials were for food products, of which $98 \cdot 2 \%$ were for non-core foods. While the use of premiums decreased compared with other commercials, the use of promotional characters in non-core food commercials increased, especially during children's programmes.

Conclusions: Children in Germany are exposed to large numbers of food commercials. The exposure to commercials for non-core foods and the use of techniques attractive to children are widespread and appear to have remained unaffected by the announcement of the EU Pledge in December 2007. We conclude that the industry's voluntary agreement has failed to fulfil its declared purpose.
\end{abstract}

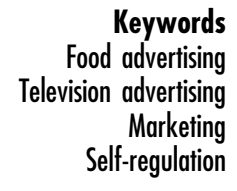

Marketing and especially advertising that is directed at children is an important public health issue. Research has supported the view that children are perhaps the most important target group for a company's marketing ${ }^{(1)}$, but may not fully understand the nature and intention of commercial messages ${ }^{(2-4)}$. Since brand bonding is established early in childhood ${ }^{(5)}$, industries have incentives to target children as early as possible in order to gain competitive advantages in the market. Research has pointed out that children misinterpret commercials as a consequence of their stage of development ${ }^{(6-8)}$, and commercials for food products may change preferences and choices regardless of the possible risk to health ${ }^{(9-14)}$. Overweight and obesity rates among German children aged 3-17 years have risen to about $15-18 \%{ }^{(15-17)}$, a strongly significant increase over the previous two decades. According to international research ${ }^{(18)}$ and sociodemographic statistics in Germany ${ }^{(19)}$, parents' role as a 'gatekeeper' filtering commercial information for their offspring has decreased. Children have become more autonomous consumers earlier in life. The regulation of advertisements directed at children in Germany however can be considered liberal: advertising containing emotionalizing elements like celebrities or cartoon characters is generally allowed and commercials are sometimes described as 'educational' by helping children learn about media. However, under pressure from the European Commission to make voluntary moves to limit marketing 
to children, the European food industry agreed in December 2007 to constrain its commercials for food to children under 12 years of age to those that fulfil[s] specific nutrition criteria'. This declaration is known as the 'EU Pledge ${ }^{\text {(20) }}$. No measures were put in place to monitor the effectiveness of the Pledge through independent evaluation.

Research on German TV advertising is scarce. To our knowledge only the German 'SOFIA group'(21) conducted a content analysis in 2005 , which found that $36.5 \%$ of commercials were for food products. The German Federation for Food Law and Food Science (Bund für Lebensmittelrecht und Lebensmittelkunde)," referring to the SOFIA study, responded by stating that food advertising only rarely targets children and denied the need for further regulation of advertising ${ }^{(22)}$. A recent paper by Kelly et $a l^{(23)}$ presents an international comparison of food commercials between countries occurring in the three most popular TV channels for children and found Germany to be the country with the highest proportion of 'non-core food commercials'. This term refers to food with high amounts of fat, salt, sugar and energy ${ }^{(23)}$.

The present paper focuses on whether non-core food advertising in Germany is directed specifically to children and whether the pattern of children's TV advertising exposure has changed since the announcement of the EU Pledge. We want to stress that the expression 'exposure' suggests advertising to be a passive phenomenon. It neglects the fact that advertising is first designed to appeal to a certain target group and second is aired when the target audience is most likely to be watching, namely during certain peak viewing times and programmes. We thus extend the findings from Kelly et al. ${ }^{(23)}$ by analysing commercial content in the ten most popular TV channels watched by German children. In order to address this question, we compare food commercials with those for toys, since the latter represents a 'classical' product group for children. The reason for this comparison is to show the importance to the food industry of targeting children by identifying similarities in the way the commercials for the two product groups are designed. Finally, we compare our findings from 2007-2008 with data from 2010 to find out if the EU Pledge has been carried out effectively.

\section{Methods}

\section{Data sampling}

Television was recorded for two weekdays and two weekend days between 06.00 and 22.00 hours from October 2007 to March 2008 for children's ten most popular German TV channels (see Table 1 for the recording

\footnotetext{
* The German Federation for Food Law and Food Science is a lobby organization of the German food industry.
}

schedule).* We defined children as being 3-13 years old and also included adolescents as being 14-19 years old. We excluded holidays and special events like Christmas to ensure that the data represent typical broadcasting. A total of $613.5 \mathrm{~h}$ for 2007 and 2008 were recorded on DVD. For the additional sampling in 2010, data were recorded for one weekday and one weekend day at the same time slots for three of the ten channels: one music channel (MTV), one entertainment channel (Pro7) and one channel for children (Nickelodeon). These channels were chosen because they represent the three main sectors of German $\mathrm{TV}^{\dagger}$ and are among the ten most popular ones for both children and adolescents. The more adolescent-oriented music channel MTV broadcasts mostly music videos, reality and lifestyle shows; the entertainment channel Pro7, which is watched equally by children and adolescents, mainly broadcasts movies, talk shows and sit-coms; while the children's channel Nickelodeon mainly broadcasts cartoon programmes like 'SpongeBob SquarePants' or soap operas. For these channels we collected a total sample of $108 \mathrm{~h}$ of data in 2010 (see Table 1 for the recording schedule).

\section{Coding}

For every commercial we classified the advertised product type (food, toys and others), the programme category in which the commercial was shown (e.g. talk show, young children's programme, music programme) and the corresponding time period in which it occurred. Channel selfpromotions were not treated as commercials and hence not included in the documentation. We also coded the time period as either peak or non-peak viewing time similar to Kelly et $a l^{(23)}$. Peak viewing times were considered as from 13.00 to 15.00 hours and from 17.00 to 21.00 hours for both weekdays and weekend days. We had to assume similarity here, because only aggregated data on viewing behaviour over the whole week were available for our study. These viewing times were defined as periods when the number of children and adolescent viewers was greater than $45 \%$ of the maximum number of viewers of that age group at any time in the day $\$$ Several countries and the EU Pledge define

\footnotetext{
* We obtained the ten most favourite channels from the survey 'Trend Tracking Kids' conducted by iconkids \& youth international research GmbH (Munich, Germany). These account for $75 \%$ of the channels watched by children on average and $96 \%$ of the channels watched by adolescents during that period. TV channels were recorded by Emma Boyland at the Kissileff Laboratory for the Study of Human Ingestive Behaviour, University of Liverpool, UK.

$\dagger$ We also conducted a cluster analysis (not presented here), which corroborated this three-part fragmentation. One might of course argue that further differences between channels within these three sectors exist. However we regarded these as not relevant for our examination.

* We derived the data on the relative amounts of children watching TV from the AGF (Arbeitsgemeinschaft Fernsehforschung; http:// www.agf.de), a consortium of German TV broadcasters. We chose $45 \%$ for calculating peak viewing times as the use of $50 \%$ of all children would have left only a small period between 19.00 and 21.00 hours as peak viewing time and the use of $40 \%$ would have widened the peak viewing period over the whole afternoon. We thus regard $45 \%$ as a differentiated coverage of target audiences for advertisers.
} 
Table 1 Recording schedule

\begin{tabular}{|c|c|c|c|c|}
\hline Channel & Dates 2007/2008 & Time slots (hours) & Dates 2010 & Time slots (hours) \\
\hline MTV & $\begin{array}{l}12 \text { Feb } 2008 \text { (Tue) } \\
13 \text { Feb } 2008 \text { (Wed) } \\
15 \text { Mar } 2008 \text { (Sat) } \\
16 \text { Mar } 2008 \text { (Sun) }\end{array}$ & $\begin{array}{l}06.00 \text { to } 22.00 \\
06.00 \text { to } 22.00\end{array}$ & $\begin{array}{l}15 \text { Sep } 2010 \text { (Wed) } \\
18 \text { Sep } 1010 \text { (Sat) }\end{array}$ & $\begin{array}{l}06.00 \text { to } 22.00 \\
06.00 \text { to } 22.00\end{array}$ \\
\hline PRO 7 & $\begin{array}{l}11 \text { Mar } 2008 \text { (Tue) } \\
13 \text { Nov } 2008 \text { (Tue) } \\
27 \text { Feb } 2008 \text { (Wed) } \\
22 \text { Mar } 2008 \text { (Sat) } \\
24 \text { Feb } 2008 \text { (Sun) }\end{array}$ & $\begin{array}{l}06.00 \text { to } 07.00 \\
07.00 \text { to } 22.00 \\
06.00 \text { to } 22.00 \\
06.00 \text { to } 22.00 \\
06.00 \text { to } 22.00\end{array}$ & $\begin{array}{l}17 \text { Sep } 2010 \text { (Fri) } \\
25 \text { Sep } 2010 \text { (Sat) }\end{array}$ & $\begin{array}{l}06.00 \text { to } 22.00 \\
06.00 \text { to } 22.00\end{array}$ \\
\hline Nickelodeon & $\begin{array}{l}19 \text { Feb } 2008 \text { (Tue) } \\
19 \text { Feb } 2008 \text { (Tue) } \\
20 \text { Feb } 2008 \text { (Wed) } \\
20 \text { Feb } 2008 \text { (Wed) } \\
23 \text { Feb } 2008 \text { (Sat) } \\
17 \text { Nov } 2007 \text { (Sat) } \\
24 \text { Feb } 2008 \text { (Sun) } \\
18 \text { Nov } 2007 \text { (Sun) }\end{array}$ & $\begin{array}{l}06.00 \text { to } 07.00 \\
07.00 \text { to } 22.00 \\
07.00 \text { to } 22.00 \\
06.00 \text { to } 07.00 \\
06.00 \text { to } 07.00 \\
07.00 \text { to } 22.00 \\
06.00 \text { to } 07.00 \\
07.00 \text { to } 22.00\end{array}$ & $\begin{array}{l}16 \text { Sep } 2010 \text { (Thur) } \\
19 \text { Sep } 2010 \text { (Sun) }\end{array}$ & $\begin{array}{l}06.00 \text { to } 22.00 \\
06.00 \text { to } 22.00\end{array}$ \\
\hline VIVA & $\begin{array}{l}4 \text { Mar } 2008 \text { (Tue) } \\
29 \text { Jan } 2008 \text { (Tue) } \\
5 \text { Mar } 2008 \text { (Wed) } \\
30 \text { Jan } 2008 \text { (Wed) } \\
1 \text { Mar } 2008 \text { (Sat) } \\
12 \text { Jan } 2007 \text { (Sat) } \\
2 \text { Mar } 2008 \text { (Sun) } \\
12 \text { Feb } 2007 \text { (Sun) }\end{array}$ & $\begin{array}{l}06.00 \text { to } 07.00 \\
07.00 \text { to } 22.00 \\
06.00 \text { to } 07.00 \\
07.00 \text { to } 22.00 \\
06.00 \text { to } 07.00 \\
07.00 \text { to } 22.00 \\
06.00 \text { to } 07.00 \\
07.00 \text { to } 22.00\end{array}$ & & \\
\hline Super RTL & $\begin{array}{l}12 \text { Feb } 2008 \text { (Tue) } \\
13 \text { Nov } 2007 \text { (Tue) } \\
13 \text { Feb } 2008 \text { (Wed) } \\
14 \text { Nov } 2007 \text { (Wed) } \\
16 \text { Feb } 2008 \text { (Sat) } \\
26 \text { Jan } 2008 \text { (Sat) } \\
17 \text { Feb } 2008 \text { (Sun) }\end{array}$ & $\begin{array}{l}06.00 \text { to } 07.00 \\
07.00 \text { to } 22.00 \\
06.00 \text { to } 07.00 \\
07.00 \text { to } 22.00 \\
06.00 \text { to } 07.00 \\
07.00 \text { to } 22.00 \\
06.00 \text { to } 22.00\end{array}$ & & \\
\hline Kabel 1 & $\begin{array}{l}19 \text { Jan } 2008 \text { (Tue) } \\
19 \text { Mar } 2008 \text { (Wed) } \\
23 \text { Jan } 2008 \text { (Wed) } \\
1 \text { Mar } 2008 \text { (Sat) } \\
2 \text { Mar } 2008 \text { (Sun) }\end{array}$ & $\begin{array}{l}06.00 \text { to } 22.00 \\
06.00 \text { to } 07.00 \\
07.00 \text { to } 22.00 \\
06.00 \text { to } 22.00 \\
06.00 \text { to } 22.00\end{array}$ & & \\
\hline RTL 2 & $\begin{array}{l}26 \text { Feb } 2008 \text { (Tue) } \\
27 \text { Nov } 2007 \text { (Tue) } \\
27 \text { Feb } 2008 \text { (Wed) } \\
28 \text { Nov } 2007 \text { (Wed) } \\
9 \text { Feb } 2008 \text { (Sat) } \\
10 \text { Feb } 2008 \text { (Sun) }\end{array}$ & $\begin{array}{l}06.00 \text { to } 07.00 \\
07.00 \text { to } 22.00 \\
06.00 \text { to } 07.00 \\
07.00 \text { to } 22.00 \\
06.00 \text { to } 22.00 \\
06.00 \text { to } 22.00\end{array}$ & & \\
\hline ARD & $\begin{array}{l}26 \text { Feb } 08 \text { (Tue) } \\
20 \text { Feb } 2008 \text { (Wed) } \\
8 \text { Mar } 2008 \text { (Sat) } \\
3 \text { Sep } 2008 \text { (Sun) }\end{array}$ & $\begin{array}{l}06.00 \text { to } 22.00 \\
06.00 \text { to } 22.00 \\
06.00 \text { to } 22.00 \\
06.00 \text { to } 22.00\end{array}$ & & \\
\hline RTL & $\begin{array}{l}5 \text { Feb } 2008 \text { (Tue) } \\
21 \text { Jan } 2008 \text { (Tue) } \\
6 \text { Feb } 2008 \text { (Wed) } \\
8 \text { Mar } 2008 \text { (Sat) } \\
10 \text { Nov } 2007 \text { (Sat) } \\
9 \text { Mar } 2008 \text { (Sun) } \\
11 \text { Nov } 2007 \text { (Sun) }\end{array}$ & $\begin{array}{l}06.00 \text { to } 07.00 \\
07.00 \text { to } 22.00 \\
06.00 \text { to } 22.00 \\
06.00 \text { to } 07.00 \\
07.00 \text { to } 22.00 \\
06.00 \text { to } 07.00 \\
07.00 \text { to } 22.00\end{array}$ & & \\
\hline SAT 1 & $\begin{array}{l}18 \text { Mar } 2008 \text { (Tue) } \\
5 \text { Mar } 2008 \text { (Wed) } \\
14 \text { Nov } 2007 \text { (Wed) } \\
9 \text { Feb } 2008 \text { (Sat) } \\
10 \text { Feb } 2008 \text { (Sun) }\end{array}$ & $\begin{array}{l}06.00 \text { to } 22.00 \\
06.00 \text { to } 07.00 \\
07.00 \text { to } 22.00 \\
06.00 \text { to } 22.00 \\
06.00 \text { to } 22.00\end{array}$ & & \\
\hline
\end{tabular}

children's programmes as those when the proportion of children compared with adults is sufficiently high, but peak viewing times derived from this rule would disregard situations in which children watch TV together with parents. All commercials were also screened for the use of premiums (competitions, gifts, games, etc.) and promotional characters (celebrities, sports persons and cartoon characters) that were likely to attract children. Several other marketing techniques that might attract children were not considered (e.g. children promoting products, animation suggesting supernatural powers, unexpected unreal events $\left.{ }^{(18,24)}\right)$. Food commercials were classified as either 'core' foods being nutrient dense 
and low in energy or 'non-core' foods being high in undesirable nutrients and/or energy, and a third category comprising 'miscellaneous' foods for products like vitamin supplements and toddler's food, following the food classification system used in previous research ${ }^{(23,25)}$. Advertised brand names were documented as the products they stood for (e.g. a fast-food brand was coded as a fast-food meal). It should be noted that several products which were classified as core foods might be classified as non-core foods according to other guidelines (e.g. meat products especially designed for children with a high content of fat, probiotic drinks known to contain high amounts of sugar). In total 248 commercials for these products in the 2007-2008 sample and five in the 2010 sample were classified as core foods.

\begin{abstract}
Analysis
The $\chi^{2}$ test was applied to determine significant differences in the proportion of food commercials for peak viewing times, children's programmes and the use of certain marketing techniques (promotional characters and premiums). We considered results significant at $P=0 \cdot 05$. Binary logistic regression was used to estimate the likelihood that non-core food commercials compared with core food commercials, toys and all other commercials contained more of the aforementioned elements that attract children. Significant coefficients in the logistic regression models, transformed into odds ratios, directly display a higher or lower propensity to be used in a non-core food commercial. We chose peak viewing time, several programme categories, promotional characters and premiums as independent dummy variables. The ranking of channel popularity among children and adolescents derived from viewing frequencies was also included as a covariate.

To address the question of whether the EU Pledge fulfilled its purpose, we compared the data from the three channels MTV, Pro7 and Nickelodeon from 2010 with the data from same three channels in 2007-2008.

Changes in the nature of the programmes between 2007-2008 and 2010 were unlikely: the channels kept their emphasis on music, entertainment and children's programming, respectively. The recorded time slots were the same in each sample. We conducted a binary logistic regression analysis on the pooled data, in which we included a dummy variable to indicate whether the commercial was from the 2007-2008 or the 2010 sample. By estimating the interaction effect of the EU Pledge variable with the other variables of interest, we are able to infer changes to child-targeted marketing in TV advertising and thus the effectiveness of the EU Pledge.
\end{abstract}

\section{Results}

\section{Descriptive statistics for 2007-2008 and 2010}

In total, 16062 commercials from 2007-2008 and 2657 from 2010 were identified. The average transmission rate across the sample was 26 commercials/h per channel in 2007-2008 and approximately 25 commercials/h per channel in 2010. Assuming that children watch about $90 \mathrm{~min}$ and adolescents about $120 \mathrm{~min}$ of TV daily, ${ }^{*}$ they are exposed to 39 and 53 commercials/d respectively or between 12000 and 19325 commercials/year. Note that these estimates are lower bounds since we did not account for the distribution of viewers and commercials during the day, i.e. more commercials are aired during times when children or other target audiences are watching. Overall in 2007-2008, 3201 (19.9\%) of all commercials were for food and beverages, and for toys it was 2816 (17.5\%). Food commercials in 2007-2008 were broadcast more on weekdays than the weekend, although this difference was not found in $2010\left(\chi^{2}=23 \cdot 618, P<0 \cdot 001\right.$ for $2007-2008$ and $\chi^{2}=1 \cdot 701, P=0 \cdot 105$ for 2010). For all channels in 2007-2008, the majority of food commercials (73\%) were for non-core foods and a minority (21\%) for core foods.

In the sample of $2010,492(18.5 \%)$ of the commercials were for foods and 425 (16\%) for toys. Of the food commercials, $483(98.2 \%)$ were for non-core foods. The figures from the same three channels in the period 2007-2008 were a total of 4925 commercials, of which $715(14.5 \%)$ were for foods, and of these $630(88 \cdot 2 \%)$ were for non-core foods. The increase over the period 2007-2008 to 2010 in the percentage of commercials that were for food, and the increase in percentage of food commercials that were for non-core foods, are both significant $\left(\chi^{2}=20 \cdot 624, P<0.001\right.$ and $\chi^{2}=24.634$, $P<0 \cdot 001$, respectively). In both samples, the use of promotional characters and the use of premiums were significantly greater for non-core food commercials compared with other commercials and greater for noncore foods than core foods. $\dagger$ Non-core foods were also advertised significantly more during peak viewing times than other commercials.

\section{Comparison of commercials for different product groups}

Table 2 shows the results of the regression analysis for non-core foods contrasted with core foods, toys and all other product categories, presenting the estimated regression coefficients, their significance and the odds for their use in the different categories of commercials. The results from the regression models are consistent with the results from the $\chi^{2}$ tests: for example, in contrast to core food commercials, non-core food commercials were

\footnotetext{
* This was the average viewing time in 2009 for children and adolescents; these data are regularly measured by the AGF.

+ Non-core food commercials $v$. other commercials: for 2007-2008 (ten-channel sample), significantly greater use of promotional characters $\left(\chi^{2}=7.393, P<0.004\right)$, premiums $\left(\chi^{2}=101 \cdot 026, P<0.001\right)$ and peak viewing times $\left(\chi^{2}=29.534, P<0.001\right)$; for 2010 (three-channel sample), significantly greater use of promotional characters $\left(\chi^{2}=141.698\right.$, $P<0.001)$, premiums $\left(\chi^{2}=3.052, P<0.048\right)$ and peak viewing times $\left(\chi^{2}=9 \cdot 732, P<0 \cdot 001\right)$. Results for non-core foods $v$. core foods are available upon request.
} 
more likely to be aired during movies and younger children's programming and especially with music videos $(\mathrm{OR}=11 \cdot 24)$. The odds for the use of promotional characters and premiums and transmission during peak viewing times for non-core foods were also significantly greater than 1 . However we found decreased odds for children's but not adolescents' ranking variable. Comparing non-core food commercials with toy commercials showed significant positive coefficients for the use of promotional characters, premiums, transmission during peak viewing times and adolescents' ranking variable. This demonstrates a higher use of these independent variables in association with non-core food compared with toy advertising. Children's ranking variable and programme categories had negative coefficients. Finally, contrasting with all other commercials, those for non-core foods had increased odds of being aired during children's programming and soap operas and during peak viewing times, and for the more frequent use of promotional characters and premiums. Both ranking variables were significantly positive.

\section{Regression analysis of food commercials before and after the EU Pledge}

To examine the effect of the EU Pledge on food commercials, a modified binary regression analysis with the inclusion of a dummy variable representing the change from 2007-2008 to 2010 was used. Non-core food commercials were compared with all other commercials. Results are shown in Table 3. We discarded several programme category variables which did not occur sufficiently in the three channels. The interaction terms, which can be interpreted as one conditioned variable on the other, for the use of promotional characters and for children's programming were significantly positive: i.e. after the introduction of the EU Pledge the use of noncore food advertising compared with other commercials containing promotional characters and being broadcast in children's programming both increased. The interaction term concerning premiums was significantly negative, suggesting a decrease of these techniques after the EU Pledge for non-core foods. It should be noted that although advertising using promotional characters decreased overall after the EU Pledge, its use in non-core food commercials compared with others rose significantly. Hence considering time trends and changes in overall commercial design, the isolated effect of the EU Pledge on food commercials rather increased the use of promotional characters. The opposite effect was found for premiums: overall the use of premiums rose significantly after the EU Pledge, whereas there was no significant increase in the use of premiums for non-core food commercials compared with other commercials after the EU Pledge. The interaction term of peak viewing times after the EU Pledge was insignificant. As a proportion of all food commercials, the amount of non-core 
Table 3 Results of modified binary regression analyses examining the effect of the EU Pledge on food commercials on German children's/ adolescents' television channels from 2007-2008 to 2010: non-core food commercials compared with all other commercials

\begin{tabular}{|c|c|c|c|c|c|}
\hline & $\beta$ & SE & Wald $\chi^{2}$ & $P$ value & OR \\
\hline Constant & $-2 \cdot 476$ & 0.096 & $671 \cdot 289$ & 0.000 & 0.084 \\
\hline Comedy & 0.541 & $0 \cdot 118$ & $20 \cdot 860$ & 0.000 & $1 \cdot 718$ \\
\hline Movie & 0.989 & 0.262 & $14 \cdot 253$ & 0.000 & $2 \cdot 687$ \\
\hline Children's programme & -0.677 & $0 \cdot 110$ & $37 \cdot 699$ & 0.000 & 0.508 \\
\hline Talk show & 0.326 & 0.200 & $2 \cdot 670$ & $0 \cdot 102$ & $1 \cdot 386$ \\
\hline Music video & -1.054 & 0.159 & $43 \cdot 807$ & 0.000 & $0 \cdot 348$ \\
\hline Soap opera & 0.635 & $0 \cdot 122$ & $26 \cdot 889$ & 0.000 & $1 \cdot 887$ \\
\hline EU Pledge & 0.529 & $0 \cdot 128$ & $17 \cdot 033$ & 0.000 & $1 \cdot 697$ \\
\hline Promotional characters & $0 \cdot 247$ & 0.093 & $7 \cdot 104$ & 0.008 & $1 \cdot 280$ \\
\hline Premiums & $1 \cdot 550$ & $0 \cdot 100$ & $240 \cdot 966$ & 0.000 & $4 \cdot 712$ \\
\hline Peak viewing time & 0.508 & 0.093 & $29 \cdot 873$ & 0.000 & $1 \cdot 663$ \\
\hline EU Pledge $\times$ promotional characters & $1 \cdot 432$ & $0 \cdot 168$ & $72 \cdot 526$ & 0.000 & $4 \cdot 188$ \\
\hline EU Pledge $\times$ premiums & -1.502 & $0 \cdot 165$ & $82 \cdot 572$ & 0.000 & 0.223 \\
\hline EU Pledge $\times$ children's programme & $0 \cdot 821$ & $0 \cdot 157$ & $27 \cdot 177$ & 0.000 & $2 \cdot 272$ \\
\hline EU Pledge $\times$ peak viewing time & -0.206 & 0.141 & $2 \cdot 138$ & $0 \cdot 144$ & 0.814 \\
\hline
\end{tabular}

food commercials rose significantly in two channels; the third channel's food advertising was entirely for non-core foods in both the 2007-2008 and 2010 samples. Taking the 2010 sample as a whole, only $1 \cdot 8 \%$ of food commercials were for core foods.

\section{Discussion}

Our analysis found that TV advertising for non-core foods was extensive on TV channels popular among German children in 2007-2008 and in 2010, and used persuasive marketing techniques. This corroborates and extends previous research ${ }^{(23)}$. The same appeared to be true for TV channels viewed by adolescents. Regression results suggested that non-core food commercials were especially directed to children, since compared with other commercials they are associated with persuasive techniques. Especially compared with toy commercials, noncore food commercials more frequently used persuasive marketing techniques.

The European Commission has relied on food companies' self-regulation for its strategy to prevent child obesity $^{(26)}$. Comparing the situation before and after the food companies' EU Pledge, the evidence presented in the current paper shows that the frequency of promotion of non-core foods and the use of critical marketing techniques remained at the same level or even increased. Promotional characters although diminishing in other commercials were still used significantly more for noncore foods than for other commercials. It seems that the EU Pledge has not had the effect that was expected of it, and that reliance on voluntary self-administered restrictions have failed to fulfil their purpose, a finding which has been suggested in previous research ${ }^{(27-30)}$ and is consistent with rational economic behaviour: from a company's view, in the presence of weak penalties, the incentives to raise revenue by marketing to children are too strong. We therefore conclude that the German food industry still directs its TV advertising towards children after the EU Pledge.

These findings have important implications for public health politics. The exposure to non-core food commercials contributes to overweight and obesity in countries of the Organisation for Economic Co-operation and Development. Considering the need to reduce this exposure and the failure of voluntary restrictions it may become necessary to use more enforceable instruments. Although we did not investigate whether the companies advertising to children in 2010 were signatories to the EU Pledge, the fact that children's exposure to commercials for non-core foods has risen since the EU Pledge underpins the view that voluntary pledges are insufficient in establishing adequate protection for children.

In Germany like in many other countries (e.g. Austria) advertisers are not allowed to appeal to children directly by law. This statute however remains without effect, as long as indirect methods like cartoon characters are used. Prohibiting commercials for unhealthy foods during children's programming appears to be an appropriate solution $^{(10,31)}$, providing this includes all times when significant numbers of children are watching. With companies increasingly using their own branded Internet sites and social networking sites to promote directly to children, further controls may need to be introduced.

Our study has some limitations: first, data collected in 2010 were recorded from only three channels and it is possible that other channels showed a reduction in the advertising of non-core foods and/or the use of childattractive marketing techniques. Second, we found no significant differences in the amount of non-core food commercials between weekdays and weekend days, but we cannot rule out time trends which might have occurred during 2010, i.e. the recorded period might coincidently be a TV season with high non-core food commercials. However this does not mitigate our conclusion that the EU Pledge remains ineffective. Third, it is necessary to interpret the findings combined. In the first 
sample promotional characters, premiums, peak viewing times and children's programming appeared to be the main parameters of non-core food advertising. After the EU Pledge, despite a decrease in the use of premiums for non-core food commercials compared with other commercials, the increased use of promotional characters broadcast especially during children's programmes indicates the failure of the EU Pledge: with advertising continuing but with a change of emphasis in the use of different techniques. A misspecification of our models by omitted variable bias can be ruled out since we did not find high correlation among any two independent variables including the regression constant. Finally, our concept of peak viewing times might only partly reflect the advertiser's strategies. Future research is necessary to account for other persuasive advertising techniques (and substituting those variables with peak times). Our concept of peak viewing time might also be criticised since it is based on a high proportion of children watching during specific times and does not in itself prove that the industry targets children. More differentiated information on peak viewing times, age and viewing behaviour is necessary in order to gain further insights into the placing of commercials, although the sizes of the main effects appear robust enough to be regarded invariant to model specifications.

\section{Conclusions}

We found evidence that commercials for non-core foods target children in Germany and this has continued in a period of supposed self-regulation to restrict such advertising. The advertisements for non-core foods appear to target children even more strongly than those for toys. Since voluntary agreements fail to solve this problem, legal regulations should be considered.

\section{Acknowledgements}

This research received no specific grant from any funding agency in the public, commercial or not-for-profit sectors. The authors declare no conflict of interest. Both T.E. and A.-C.W. analysed the data and wrote the paper. The authors express deep thanks to Emma Boyland, Jason Halford and everyone at the Kissileff Laboratory for the Study of Human Ingestive Behaviour at the School of Psychology/University of Liverpool, UK for doing the recording of the TV data in 2007-2008 and helping to inform this research. They would also like to thank Tim Lobstein for help and useful comments.

\section{References}

1. McNeal JU (2007) On Becoming a Consumer - Development of Consumer Behavior Patterns in Childhood, 1st ed. Oxford: Butterworth-Heinemann/Elsevier.
2. Robertson TS \& Rossiter JR (1974) Children and commercial persuasion: an attribution theory analysis. J Consum Res $\mathbf{1}$, $13-20$.

3. Gorn GJ \& Goldberg ME (1982) Behavioral evidence of the effects of televised food messages on children. J Consum Res 9, 200-205.

4. Wilson G \& Wood K (2004) The influence of children on parental purchases during supermarket shop. Int J Consum Stud 28, 329-336.

5. LaTour K, LaTour MS \& Zinkhan GM (2010) Coke is it: how stories in childhood memories illuminate an icon. J Bus Res 63, 328-336.

6. Oates C, Blades M \& Gunter B (2001) Children and television advertising: when do they understand persuasive intent? J Consum Behav 1, 238-245.

7. Moses LJ \& Baldwin DA (2005) What can the study of cognitive development reveal about children's ability to appreciate and cope with advertising? J Public Policy Mark 24, 186-201.

8. Gialitakis G \& Chryssochoidis G (2006) Schoolchildren's understanding of food labels. Young Consumers 7, 19-25.

9. Zimmerman FJ \& Bell JF (2010) Associations of television content type and obesity in children. Am J Public Health 100, 334-340.

10. Halford JCG, Boyland EJ, Cooper GJ et al. (2008) Children's food preferences: effects of weight status, food type, branding and television food advertisements (commercials). Int J Pediatr Obes 3, 31-38.

11. Chou SY, Rashad I \& Grossman M (2008) Fast-food restaurant advertising on television and its influence on childhood obesity. J Law Econ 51, 599-618.

12. Engels RCM, Hermans R, Van Baaren RB et al. (2009) Alcohol portrayal on television affects actual drinking behaviour. Alcohol Alcohol 44, 244-249.

13. Borzekowski DLG \& Robinson TN (2001) The 30-second effect: an experiment revealing the impact of television commercials on food preferences of preschoolers. $\mathrm{J} \mathrm{Am}$ Diet Assoc 101, 42-46.

14. Dixon HG, Scully ML, Wakefield MA et al. (2007) The effects of television advertisements for junk food versus nutritious food on children's food attitudes and preferences. Soc Sci Med 65, 1311-1323.

15. Kurth BM \& Schaffrath Rosario A (2007) Die Verbreitung von Übergewicht und Adipositas bei Kindern und Jugendlichen in Deutschland. Ergebnisse des bundesweiten Kinder- und Jugendgesundheitssurveys (KIGGS). Bundesgesundheitsblatt Gesundheitsforschung Gesundheitsschutz 50, 736-743.

16. Berg S, Galm C, Klenk J et al. (2007) URMEL-ICE (Ulm Research on Metabolism, Exercise and Lifestyle Intervention in Children): Prävalenz von Übergewicht bei Ulmer Schulkindern-Veränderungen in 30 Jahren. Monatsschr Kinderbeilkd 155, 873 (abstract).

17. Grimmer Y, Vitt J, Jennen-Steinmetz C et al. (2008) Hohe Persistenz von Übergewicht bei Kindern der Mannheimer Risikostudie. Monatsschr Kinderbeilkd 156, 365-370.

18. Schor JB (2004) Born to Buy - The Commercialized Child and the New Consumer Culture. New York: Scribner.

19. Destatis (Statistisches Bundesamt) (2010) Wiesbaden: Pressekonferenz „Alleinerziehende in Deutschland Ergebnisse des Mikrozensus 2009“. http://www.destatis. de/jetspeed/portal/cms/Sites/destatis/Internet/DE/Presse/ $\mathrm{pk} / 2010 /$ Alleinerziehende/Statement_Egeler_PDF.property $=$ file.pdf (accessed October 2010).

20. www.eu-pledge.eu (2007) Food and drink companies pledge to change advertising to children. Press release. http://www.eu-pledge.eu/press.php?id=1 (accessed November 2010).

21. Becker C, Bizer K, Führ M et al. (2005) Lebensmittelwerbung für Kinderprodukte - Strategieentwürfe für den 
vorbeugenden Verbraucherschutz. http://www.bmelv.de/ cln_044/nn_749118/SharedDocs/downloads/03Ernaehrung/ EndberichtWerbungKinderlebensmittel.templateId $=$ raw . property $=$ publicationFile.pdf/EndberichtWerbungKinder lebensmittel.pdf (accessed August 2010).

22. Bund für Lebensmittelrecht und Lebensmittelkunde eV (2008) Wissenschaftliche Daten zu Ernährung, Bewegung und Übergewicht. BLL-Positionspapiere und politische Stellungnahmen. http://www.bll.de/positionspapiere/wissenschaftlichedaten-uebergewicht.html (accessed November 2010).

23. Kelly B, Halford JCG, Boyland EJ et al. (2010) Television food advertising to children: a global perspective. Am J Public Health 100, 1730-1736.

24. Page RM \& Brewster A (2007) Emotional and rational product appeals in televised food advertisements for children: analysis of commercials shown on US broadcast networks. J Child Health Care 11, 323-340.

25. Australian Dept of Health and Aging (2001) Australian guide to healthy eating. http://www.health.gov.au/internet/ wcms/Publishing.nsf/Content/healthpubhlth-strateg-foodguide-index.htm (accessed August 2010).

26. Commission of the European Communities (2007) White Paper on a Strategy for Europe on Nutrition, Overweight and Obesity related health issues. $\operatorname{COM}(2007) 279$ final. http://ec.europa.eu/health/ph_determinants/life style/nutrition/documents/nutrition_wp_en.pdf (accessed November 2011).

27. King L, Hebden L, Grunseit A et al. (2011) Industry self regulation of television food advertising: Responsible or responsive? Int J Pediatr Obes 6, e390-e398.

28. Hebden LA, King L, Grunseit A et al. (2011) Advertising of fast food to children on Australian television: the impact of industry self-regulation. Med J Aust 195, 20-24.

29. Potvin Kent M, Dubois L \& Wanless A (2011) Food marketing on children's television in two different policy environments. Int J Pediatr Obes 6, e433-e441.

30. Harris JL, Sarda V (2011) Rudd Report: Trends in Television Food Advertising to Young People: 2010 Update. http://www.yaleruddcenter.org/resources/upload/docs/ what/reports/RuddReport_TVFoodAdvertising_6.11.pdf (accessed July 2011).

31. Veerman JL, Van Beeck EF, Barendregt JJ et al. (2009) By how much would limiting TV food advertising reduce childhood obesity? Eur J Public Health 19, 365-369. 